has been questioned, owing to the fact that a highly confused chromosome complex has been found in the mule.

There is here, however, an indisputable case of mule-fertility, and the theoretical assumptions are thereby shown to be invalid.

Natal Museum, Pietermaritzburg,

ERnest Warren. Nov. 22.

\section{Vocal Powers of Kangaroos.}

IN the notes on Sir Peter Chalmers Mitchell's address to the British Association on "Zoos and National Parks ", the statement is made that the "kangaroo is never known to utter any kind of sound normally", etc. This is misleading, as, under entirely 'normal' conditions, kangaroos of several species, both ' in the wild ' and in captivity, frequently make two distinct sounds and occasionally a third

(1) A soft, frequently repeated, 'chittering' sound, made without perceptible movement of the lips and possibly produced by expulsion of air through the nostrils. In pet kangaroos it is frequently produced when the animal responds good-humouredly to gentle teasing, but amongst the gregarious small wallabies (Thylogale) a very similar sound is used by females to recall young to the pouch.

(2) A loud, discordant, aspirate sound, which may be roughly imitated by the long-drawn-out enunciation of the word 'harsh'. Chiefly indicative of anger and of pain, it is almost always heard when a wounded male is approached, and is sometimes used also by the rutting bucks, in the concluding phases of their pursuit of the females.

(3) A distinct, short, clear-cut bark or cough, made as a warning signal by a member of a 'mob', when suddenly disturbed. Although mentioned more than once in the older literature on Australian natural history, it is not given much eredence here, but I can vouch for its reality from personal experience, having heard it on two occasions, in Gippsland and southern New South Wales, when observing parties of Macropus giganteus typicus at close quarters in heavy timber, and once (by $M$. giganteus fuliginosus) in the Zoological Gardens at Adelaide.

South Australian Museum,

\section{H. H. FINLAYSON} Adelaide,

Nov. 22, 1931

1 NATURe, 128, 578, Oct. 3, 1931.

\section{St. Kilda House Mouse.}

The St. Kilda house mouse (Mus musculus muralis, Barrett-Hamilton) received great notoriety when the island was evacuated in 1930 , because it was con. fidently expected to become extinct. Some previous writers (Ritchie, Scot. Nat., 1930) stated that the mouse was confined to the Post Office buildings on the island. A visit to St. Kilda this summer proved to us that the mouse has become extremely rare and at present only inhabits two houses in which food was left behind. It is particularly interesting to note that neither of these houses is the Post Office, and the evidence of the inhabitants, and of previous visitors, confirms the view that the mouse was never confined to one building.

Waterston (Ann. Scot. Nat. Hist., 1905) described a number of house mice from Lochmaddy, N. Uist, which in every way resembled the light-bellied $M u s$ musculus muralis, and were found living with the normal Mus musculus, but apparently without hybrids. This discovery seems to have been overlooked by sub. sequent investigators, and points to the mouse not having such a confined geographical distribution as is generally credited to it.

Pembroke College, Cambridge.

Department of Zoology, The University, I.eeds.

\section{Cytology of Mycetozoa.}

IN her paper entitled "The Life-History and Cytology of Didymium nigripes Fr.", 1 Dr. E. J. Cadman has made a valuable contribution to the literature on Mycetozoa. The principal points described by her are the following : the active swarmcells possess what she terms a "centroblepharoplast" and cone apparatus connecting the flagellum with the nucleus; the nucleus of the swarm-spores has four chromosomes; a definite myxamœboid stage occurs when all trace of cone-apparatus disappears; the myxamœbæ unite in pairs as gametes to form a zygote or young plasmodium, and their nuclei also fuse; the fusion nucleus contains eight chromosomes, a diploid number characteristic of all succeeding nuclei of the plasmodium; meiosis occurs in the nuclei of the young sporangium before spore-formation, when a heterotypic division with four U-shaped chromosomes is swiftly followed by a homotypic division with four nearly spherical chromosomes.

Schunemann, ${ }^{2}$ working with the typical form of D. nigripes-Dr. Cadman deals entirely with var. xanthopus of that species-also observed the union of myxamœbæ to form gametes, but he did not see fusion of their nuclei; he also describes meiosis in the nuclei of the young sporangium before sporeformation. He found the number of chromosomes in the nuclei of the swarm-cells and plasmodium to be eight and sixteen respectively. It is interesting that the var. xanthopus, a variety apparently closely allied to the typical form, should be found by Dr. Cadman to possess only half the number of chromosomes in those two stages.

By way of criticism, several points may be noted. Dr. Cadman says (p. 106) that "the spore-membrane consists of a single membrane, not a double one as stated in Lister's Monograph". The statement is undoubtedly too general and should have been qualified; double spore-walls occur, however, in several species of the genus Didymium, in Mucilago, and in species of Trichia, as observed by De Bary ${ }^{3}$ and others. Dr. Cadman disregards the numerous completely satisfactory monospore cultures carried out by Jahn ${ }^{4}$ in Didymium squamulosum Fr., and by Miss Cayley ${ }^{5}$ and also by Schunemann in $D$. nigripes and $D$. difforme Duby, when all stages in the lifehistory, the germination of the spore, the increase of swarm-cells, and the formation of healthy plasmodia and sporangia were followed. Dr. Cadman seems scarcely to give due weight to the observations of Miss Cayley and Miss Waterhouse, who succeeded in watching in thirteen instances the gradual fusion of flagellate gametes in living monospore and plurispore cultures of $D$. difforme. She is not quite correct in stating that Miss Cayley considers that sex-segregation is closely connected with meiosis, for, although Miss Cayley's diagram illustrating the stage at which sex-segregation might occur is rather misleading, she writes (1.c. 245), " there is no experimental proof that the first division of the emerging swarm-spore is the critical one as far as sex is concerned "; and indeed her view is that, although the evidence is not conclusive, her observations, and Jahn's, tend to show

No. 3247 , VoL. 129] 